\title{
PATRIARCHY REPRODUCTION IN MAMAH DEDEH'S DA'WAH MATERIALS
}

\section{Defriyanti Puluhulawa}

Interdiciplinary Islamic Studies, Universitas Islam Negeri Sunan KalijagaYogyakarta

Email: Defriyanti01@gmail.com
ABSTRAK : Budaya patriarki merupakan sistem yang menempatkan laki-laki pada posisi laki-laki nomor satu satau posisi superior sedangkan perempuan di posisi nomor dua sebagai subordinat. Sistem ini sudah lama telah di langgengkan oleh masyarakat, tak terkecuali dalam teks-teks agama itu sendiri. Dalam materi dakwah pun banyak di temukan hal-hal yang melenggangkan budaya patriarki. Salah satunya dalam materinya Mamah Dedeh. Disini Mamah Dedeh dalam memberikan dakwah ia lebih banyak mengangkat tentang masalah keluarga. Akan tetapi disini banyak melanggengkan.

Dalam pendekatan penelitian peneliti menggunakan motode penelitian kualitatif, yang mana dalam pendangan Ceswell yang di kutip dari bukunya J.Raco bahwa penelitian kualitatif yaitu mengeplorasi dan mampu memahami suatu gejala. Untuk penelitan kualitatif menggunakan deskriktif analitis yang mana metode ini memiliki fungsi untuk menganalisis dan menghimpun berbagai dokumen yang sudah terjamin keabsahan. Karena kegiatan analisis ini ditujukan untuk mengetahui kedudukan, makna. Sedangkan untuk jenis penelitian menggunakan analisis isi (content analisis). Analisis isi merupakan teknik penelitian yang digunakan untuk memahami pesan simbolik atau teks-teks tertentu.

Berdasarkan hasil penelitian maka dapat disimpulkan bahwa budaya patriarki sudah ada sejak zaman dahulu bahkan sampai hari ini budaya patriarki masih saja 
di langgengkan. Dalam materi dakwahnya Mamah Dede pun banyak di temukan bahwa materi-materi yang di sampaikan banyak melanggengakan budaya patriarki pertama, Suami adalah kepala keluarga dan istri jadi kepala rumah tangga dari kaluarga suaminya, ngurusin anak ngurusin rumah tangga itu pekerjaan istri”. Pernyataan ini sangat patriarki karena menjadikan perempuan nomor dua sedangkan laki-laki nomor satu. Kedua, Saya lebih memilih bekerja di dalam rumah daripada bekerja di kantor walaupun berpendidikan tinggi. Pernyataan kedua ini memberikan suatu pemahaman bahwa perempuan tidak layak untuk bekerja di luar, perempuan lebih pantas bekerja di dalam rumah. Pemahaman terhadap ayat-ayat alquran dan hadits membutuhkan suatu penafsiran ulang dengan melihat konteksnya yaitu perbedaan zaman dulu dan zaman sekarang agar tidak menimbulkan bias gender ataupun pelanggengan budaya patriarki.

Kata Kunci : Patriarki, Dakwah, Mamah Dedeh 


\section{PENDAHULUAN}

Islam merupakan agama yang di turunkan Allah kepada Nabi Muhammad untuk menyempurnakan agama agama samawi sebelumnya. Oleh karena itu Islam mengatur berbagai aspek kehidupan baik itu mengenai Ibadah seperti sholat, puasa, zakat dll juga dalam bidang ekonomi, sosial maupun politik. Dalam perkembangannya Islam dapat tersebar karena adanya Dakwah makanya Islam dapat di katakan adalah agama dakwah. Artinya agama yang selalu mendorong pemeluknya untuk senantiasa mengajak manusia kedalam Islam . Maju mundurnya umat Islam sangat bergantung dan berkaitan erat dengan kegiatan dakwah. Sehingga dakwah menempati posisi tertinggi dan mulia dalam kemajuan agama Islam (Harjani, Hefni and Yusuf 2003, 4).

Dakwah jika di tinjau dari segi bahasa berarti panggilan, seruan atau ajakan. Bentuk perkataan tersebut dalam bahasa Arab disebut masdhar. Sedangkan bentuk kata kerja (fi'il) nya adalah berarti, memanggil, menyeru dan mengajak ( $D a^{\prime} a$, Yad'u Da'watan). Sedangkan dakwah secara terminologi merupakan bagian yang sangat esensial dalam kehidupan seorang muslim, dimana esensinya berada pada ajakan atau dorongan (motivasi), rangsangan atau bimbingan terhadap orang lain untuk menerima ajaran agama Islam dengan penuh kesadaran, oleh karena itu untuk sasaran syang di inginkan maka yang harus di perhatikan adalah materi yang akan di sampaikan karena ini sangat mempengaruhi objek dakwah (Mad'u). ( Amin and Zirzis 2 2009 2 6)

Materi dakwah sendiri merupakan pesan-pesan dakwah Islam atau segala sesuatuyang harus di sampaikan subjek kepada objek dakwah yaitu keseluruhan ajaran Islam yang ada di dalam kitabullah maupun Sunnah RasulNya. Pesan-pesan dakwah yang di sampaikan objek dakwah yang berisi ajaran-ajaran Islam (Amin and Zirzis 2009, 88)

Dalam beberapa materi dakwah yang di sampaikan oleh subjek dakwah (Da'i) ternyata masih banyak yang tidak sesuai dengan kebutuhan masyarakat terutama perempuan, karena materi yang di sampaikan masih banyak melanggengkan sistem patriarki. Salah satunya materi yang di sampaikan oleh Mamah Dede. Walaupun Mamah Dedeh adalah seorang perempuan akan tetapi dia masih melaggengkan sistem patriarki hal ini dapat di lihat melalui ceramah yang ia bawakan, sehingga dalam hal ini peneliti merasa tertarik untuk menjadikan ini sebagai objek penelitian, dengan judul "Pelanggengan sistem petriarki dalam materi dakwah Mamah Dedeh".

\section{Tinjauan Pustaka}

Tinjauan pustakan ini merupakan informasi rujukan yang penulis gunakan untuk penyususnan penelitian ini. Hal ini dimaksudkan agar tidak terjadi kesamaan plagiatisasi dalam penyusunan, maka penulis melakukan telaah pustaka dengan menyandingkan dan membandingkan penelitian ini dan penelitan sebelumnya, penelitian tersebut antara lain:

Pertama penelitian yang dilakukan oleh Septiana Nur dengan judul "Khalayak program dakwah dan relasi perempuan dan laki-laki dalam keluarga (Analisis persepsi 
ibu-ibu pengajian husnul khotimah perumahan Bumi asri, kabupaten Tangeran terhadap pesan program Mamah dan Aa Ber-aksi di Indosiar). Tujuan peelitian ini lebih berfokus pada bagaimana Ibuibuyang ada di perumahan Bumi Asri memaknai pesan Mamah Dedeh terkait dengan Gender.

\section{Metode Penelitian}

Dalam pengdekatan penelitian peneliti menggunakan motode penelitian kualitatif, yang mana dalam pendangan Ceswell yang di kutip dari bukunya J.Raco bahwa penelitian kualitatif yaitu mengeplorasi dan mampu memahami suatu gejala. Untuk penelitan kualitatif menggunakan deskriktif analitis yang mana metode ini memiliki fungsi untuk menganalisis dan menghimpun berbagai dokumen yang sudah terjamin keabsahan. Karena kegiatan analisis ini ditujukan untuk mengetahui kedudukan, makna.

Sedangkan untuk jenis penelitian menggunakan analisis isi (content analisis). Analisis isi merupakan teknik penelitian yang digunakan untuk memahami pesan simbolik atau teks-teks tertentu (Siyoto and Sodik 2015, 125).

\section{PEMBAHASAN}

\section{Memahami gender dan patriarki}

\section{Gender}

Kata gender dalam istilah bahasa Indonesia sebenarnya diserap dari habasa Inggris, yaitu 'gender. Dalam hal ini jika dilihat dalam kamus bahasa Inggris, secara tidak jelas ini dibedakan antara sex dan gender. Sering kali gender dipersamakan dengan seks (jenis kelamin laki laki dan permpuan). Dalam memahami suatu konsep gender kita harus dapat membedakan antara kata gender dan seks (Dwijowijoto 2008, 1). Seks dapat diartikan sebagai jenis kelamin yang di tentukan secara biologis. Maksud perbedaan biologis adalah perbedaan yang di dasarkan pada hal hal yang bersifat permanen dan tidak dapat di pertukarkan. Misalnya, laki laki mempunyai penis, sementara perempuan mempuanyai vagina. Perempuan mampu mempunyai payudara yang dapat memproduksi makanan untuk anak, sementara laki-laki tidak. Pendeknya disini perbedaan tidak dapat di pertukarkan, sesuatu yang tidak dapat di rubah dari waktu kewaktu maupun dari satu tempat ke tempat yang lain lebih bersifat paten (Khoiruddin Nasution 2016, 260).

Sementara itu Gender dalam pandangan Mosse merupakan seperangkat peran yang seperti halnya sebuah topeng atau kostum di sebuah teater, menyampaikan kepada orang orang lain kita adalah feminin atau maskulin. Perangkat perilaku ini mancakup sebuah penampilan, pakaian, sikap, kepribadian, dan bekerja di dalam dan diluar rumah taangga, seksualitas, tanggung jawab keluarga dan sebagaianya secara bersamasama memoles peran gender kita. Jadi gender bukanlah sebuah kodrat ataupun sebuah ketentuan Tuhan, oleh karena itu gender sangat berkaitan erat dengan proses keyakinan sebagaimana laki-laki dan perempuan berperan dan bertindak sesuai dengan tata nilai yang telah terstruktur, dalam ketentuan sosial dan budaya di 
tempat mereka berada. Dengan kata lain perempuan dan laki-laki dalam peran, fingsi, hak, perilaku yang telah di bentuk oleh ketentuan sosial dan budaya setempat (Mosse and Fakih 2007, 3). Gender tidak bersifat Universal namun bervariasi dari masyarakat satu ke masyarakat yang lain dari waktu ke waktu. Sekalipun demikian, ada dua elemen gender yang bersifat universal, yaitu gender tidak identik dengan jenis kelamin dan gender merupakan dasar bagi pembagian kerja di semua masyarakat.

Dalam pandangan Inayah yang di kutib dari (Aini,_2015), gender adalah konstruksi sosial bukan suatu yang biologis. Sifat siafat ini dilabelkan di setiap masing-masing merupakan sebuah pelabelan yang tidak permanen., yang bisa berubah dan berbeda, dan dapat pula untuk dipertukarkan. Misalnya, bahwa perempuan itu di kenal dengan lemah lembut, cantik, emosional, atau keibuan. Sedangkan laki-laki di anggap kuat, rasional, jantan dan perkasa. Konsep gender mampu melahirkan bipolaritas sifat, peran dan posisi yang tersubordinasi dan mensubordinasi. Sehingga gender ini daat mengacu pada sebuah ide atau pandangan yang ditentukan secara sosial tentana bagaimana menjadi seorang "perempuan" atau laki-laki. Dalam sebuah masyarakat yang memiliki banyak norma, adat, dan aturan membuat munculnya perbedaan-perbedaan terkonstruksi secara sosial.

Gender secara tidak sadar telah membentuk suatu budaya yakni budaya patriarkal yang menciptakan budaya dominasi yang mengakibatkan menculnya ketidak adilan. Bahwa dalam suatu bentuk ketidak adilan gender antara lain adanya subordinasi, marginalisasi, stereotip dan kekerasan terhadap perempuan. Adanya suatu suberdinasi yang nantinya akan memunculkan suatu marginalisasi, yakni suatu proses peminggiran yang merugikan salah satu pihak. Dalam suatu literatur feminis, marginalisasi merupakan sebuah ekspresi dari dampak hubungan suatu dialektis hirarkis antara laki-laki dan perempuan. Kemudian memunculkan stereotif yang akan memberikan dampak kepada subordinasi perempuan di wilayah publik domestik dan akan mengakibatkan peminggiran dari ruang gerak perempuan (Aini, 2015)

\section{Patriarki}

Menurut Sylvia walby patriarki suatu sistem struktur sosial dan praktik praktik dimana laki-laki yang lebih mendominasi, menindas dan mengekplotasi perempuan. Dalam penggunaaan istilah struktur sosial ini jelas menunjukan penolakan terhadap determinisme biologis, dan menolakan gagasan bahwa setiap individu laki-laki berada pada posisi dominan dan setiap perempuan dalam posisi subordinat(Walby. 2014 2 28).

\section{Patriarki}

butuh dikonseptualisasikan pada berbagai level abstraksi. Pada level yang paling abstrak patriarki berwujud sebagi sebuah sistem relasi sosial. Pada sebuah level yang kurang abstrak patriarki terdiri dari enam struktur yaitu mode reproduksi patriarki, relasi patriarki pada pekerjaan dengan 
upah, relasi patriarki dalam seuah keluarga, kekerasan laki-laki, relasi petriartki dalah hal seksualitas, dan relasi patriarki dalam lembaga budaya. Lebih kengkret lagi, dalam hal relasi masingmasing struktur tersebut, adalah mungkin untuk mengidentifikasi praktik patriarki yang diendapkan secara mendalam.

Keenam struktur ini mempunyai sebuah efek sebab akibat satu dengan yang lain, baik peneguhan maupun pemblokiran, tetapi masing masing lumayan otonom. Pengkhususan beberapa srtuktur ketimbang secara sederhana satu basis penting untuk menghindari reduksionisme dan esensialisme.

a. Relasi produksi patriarki di dalam sebuah keluarga adalah sebuah struktur pertama. Melalui struktur inilah sebuah pekerjaan rumah tangga perempuan yang diambil alih oleh suami mereka atau orang orang yang tinggal bersama mereka. Jadi seongan perempuan bisa jadi menerima sebuah pemeliharaan sebagai ganti rugi dari pekerjaan mereka, khususnya saat dia tidak memiliki pekerjaan dengan upah. Maka ibu rumah tangga adalah kelas yang memproduksi, sementara para suami adalah kelas pengambil alih.

b. Struktur patriarki kadua level ekonomi adalah relasi patriarki dalam pekerjaan dengan upah. Dalam sebuah bentuk penutupan patriarki yang kompleks di dalam sebuah pekerjaan dengan gaji melaran perempuan masuk ke dalam jenis pekerjaan yang lebih baik dan memisahkan mereka ke dalam pekerjaan yang lebih buruk dan menganggap mereka kurang terampil (W_alby_2014, 29).

c. Negara juga sangat patriarki sekaligus kapitalis dan risialis. Karena arena perjuangan dan bukan sebagai entitas minolitis, negara juga memiliki bias terhadap kepentingan patriarki seperti tampak pada dalam kebijakan-kebijakan dan tindakannya.

d. Kekerasan laki-laki membentuk struktur yang lebih lanjut, yang terlepas dari kejadiannya yang tampak individualis dan muncul dalam bentuk yang beragam. Perilaku rutin ini yang di alami perempuan oleh perbuatan laki laki, dengan akibat standar dan perilaku kebanyakan perempuan. Kekerasan ini yang di lakukan oleh laki-laki terhadap perempuan secara sistematis dimaafkan dan disahkan oleh penolakan negara untuk campur tangan dalam melawan kekerasan tersebut kecuali dalam kejadian kejadian khusus, meskipun praktik pemerkosaan, dan pemukulan terhadap istri, pelecehan seksual dll.Terlalu dalam 
desentralisasidalam praktik mereka sebagai bagian dari negara itu sendiri.

e. Relasi patriarki dalam seksualitas mampu membentuk struktur kelima. Heteroseksualitas yang sifatnya wajib dan standar ganda seksual merupakan dua bentuk kunci dari struktur ini.

f. Lembaga lembaga budaya patriarki melengkapi susunan dari struktur tersebut. Lembaga-lembaga ini sangat penting untuk membangkitkan berbagai variasi sebjektivitas gendr dalam bentuk yang berbeda-beda. Struktur ini terdiri dari seperangkat lembaga yang mempu menciptakan representasi perempuan dari pandangan patriarki dalam berbagai arena di antaranya seperti agama, pendidikan dan media (W- alby 2014 2 30).

Pada masyarakat patriarki laki-laki lebih diposisikan superior terhadap perempuan. Dalam bentuk estrimnya, peran perempuan terkotak di ranah domestik, sementara ranah publik adalah ranah monopoli laki-laki. Walaupun di sektor domestik perempuan selalu di posisikan sebagai subordinat laki-laki, hal ini seperti dalam sebuah kontrol terhadap hak milik tumah tangga, dalam sebuah distribusi pekerjaan rumah tangga, atau dalam pengmbilan keputusan rumah tangga. Status :kepala keluarga" yang umumnya selalu di konotasi pada suami yang mempunya konotasi "kekuasaan," sementara kata "ibu rumah tangga;" bahkan "ratu rumah tangga" selalu melekat pada istri yang lebih berkootasi pada "pengabdian" atau "pelayanan" daripada "kekuasaan".

Karena dalam masyarakat patriarkhi, kontrol sumber daya selalu ada di tangan seorang laki-laki, dan warrisan lebih bannyak terdapat pada laki-laki. Dalam subuah masyarakat Hindu Bali anak perempuan tidak mempunyai hak waris, meskipun ia tidak mempunya saudara laki-laki. Kasus seperti ini, harta warisan jatuh ke tangan laki-laki yang sudah meninggal. Dalam masyrarakat Islam sendiri hak waris seorang perempuan adalah setengah dari hak waris yang di dapat oleh laki-laki (Darwin 2001, 4).

Makna pengabdian dan pelayanan dari istri tampak dari keharusan istri melayani suaminya, buka keharusan suami dan istri untuk saling melayani. Dalam hal berhubungan seksual, seringkali istri diperlakukan sebagai objek seksual suami, bukan petner yang memiliki hak seksualitas yang setara. Adapun seksual dalam rumah tangga, termasuk pemerkosaan dalam rumah tangga (marital ra/pes), sering terjadi, baik di masyarakat desa maupun masyarakat kota, baik pada kalangan yang kurang dalam pendidikan maupun maupun kalangan yang bisa di katakan sudah berpendidikan, baik pada keluarga yang mempunyai latar belakang pemahaman agama yang kurang maupun yang sudah memiliki pemahaman agama. Fenomena ini pun oleh masyarakat 
(termasuk oleh kaum perempuan) yang acap kali tidak di anggap suatu yang prombematis, tetapi merupakan suatu kodrat yang harus diterima dan di jalani

Hubungan yang hegemonis seperti ini juga tercermin dalam perilaku yang berkaitan dengan sebuah proses reproduksi, yaitu kehamilan, melahirkan, dan menyusui. Kehamilan adalah pengalaman yang ekslusif perempuan yang tidak akan pernah di alami oleh laki-laki, tetapi dalam proses kemilan dan konsekuensi yang menyertainya (perlunya penjagaan gizi ibu hamil, perawatan kehamilan secara teratur, penyesuaian atau kontrol dalam hubungan seksual) merupakan kepentinga kedua pasangan, laki-laki dan perempuan, dan karenanya harus menjadi tanggung jawab keduanya. Dalam banyak kasus suami (kurang memberikan perhatian di dalam menjaga dan merawat kehamilan istri. Hegemoni laki-laki dan subordinasi perempuan terjadi sejak lama yang sudah diterima sebagai yang kodrat yang tidak perlu dipermasalahkan (Darwin 2001, 5)

\section{Reproduksi patriarki dalam materi dakwah Mamah Dede}

Patriarki merupakan suatu bentukan budaya setempat dimana seorang laki laki menjadi nomor satu sedangkan perempuan selalu menjadi nomor dua dan hal ini telah mengakar pada masyarakat dan dapat dikatakan budaya petriarki ini memang sulit intuk rubah. Selain itu budaya patriarki tidak hanya dilanggengkan oleh laki-laki yang tidak ingin posisinya di ambil alih oleh seorang perempuan akan tetapi adapula perempuan-perempuan yang masih melanggengkan budaya patriarki. Dalam hal ini budaya patriarki yang dilanggengkan oleh perempuan biasanya di suarakan melalui ceramah ceramah yang ada. Salah satu pelanggengan budaya patriarki dapat di temukan melalui ceramah ceramah Mamah Dede. Adapun bentuk-bentuk pelanggengan budaya patriarki dalam konten dakwah Mamah Dedeh diantaranya

a. Laki-laki yang menjadi pemimpin dalam rumah tangga

Mamah Dede misalnya menyampaiakn seperti ini

"Suami adalah kepala keluarga 'Arrijalu kawamuna ala nisa' kalo kepala rumah tangga suami, istri itu di bawah pimpinan suami. Suami kalo jadi kepala rumah tangga istri jadi kepala rumah tangga dari kaluarga suaminya, ngurusin anak ngurusin rumah tangga itu pekerjaan istri”.

Dari pernyataan ini dapat di katakan Mama Dede masih melanggengkan budaya patriarki dengan menjadikan laki-laki adalah yang nomor satu dan perempuan di bawah laki-laki. Penyampaian Mamah Dede telah membangun sebuah subordinasi dan stereotipe bahwa dalam rumah tangga, bahwa laki-laki lah yang memimpin, yang mencari napkah atau yang harus bekerja di ruang publik, sedangkan perempuan pekerjaannya di ruang privat 
yaitu mengurus rumah dan juga anak anak dan melayani suami. Jika meminjam teorinya Piere Bourdieu tentang dominasi maskulin bahwa adanya suatu konstruksi secara biologis terutama atas tubuh baik itu maskulin atau feminin, atas penggunaan-penggunaan dan fungsi-fungsinya dalam reproduksi biologis. Konstruksi ini memberikan sebuah dasar yang kelihatannya natural bagi visi androsentris pembagian kerja secara seksual ataupun pemisahan seks dalam kerja. Maka dengan itu konstruksi tersebut memberikan suatu landasan yang kelihatannya sangat ilmiah bagi seluruh kosmos (Bourdieu_ 2010, 34). Adapun jika di lihat dari kacamatanya Barbara Rogers dalam bukuny mosse bahwa perempuan dibatasi dalam ruang lingkup rumah tangga bisa di katakan sebagai domistifikasi perempuan (domestification of women).

Selain itu Mamah Dedeh juga melontarkan sebuah pernyataan yang dimana terlihat disini melanggengkan patriarki “ Saya lebih memilih bekerja di dalam rumah daripada bekerja di kantor walaupun berpendidikan tinggi”. Pernyataan ini menggambarkan walaupun perempuan berpendidikan tinggi dia seharusnya menjadi ibu rumah tangga adalah lebih baik. Seakan-akan Mamah Dedeh mengindikasikan bahwa pekerjaan perempuan yang wajib adalah di rumah hal ini sangat bias gender menjadikan perempuan hanya di ruang privat domestik sedangkan laki-laki bebas dimana saja hal ini mempersempit ruang perempuan untuk mengekspresikan hidupnya di luar. berempuan terlalu menggunakan
perasaan

Lanjut pernyataan Mamah Dedeh "Hati seorang perempuan itu rapuh, kalo suaminya ngomongonya terlalu diktator tak tak bisa patah". Dalam pernyataan ini Mamah Dede melihat bahwa laki-laki dan perempuan ini berbeda dan sudah membawa kodrat masih masing bahwa laki-laki itu maskulin sedangkan perempuan ini feminin. Padahal hal sangat berkaitan dengan gender itu sendiri, dimana bahwa gender bukanlah suatu kodrati melainkan suatu konstruks dan hal ini sebenarnya bisa di pertukarkan bahwa perempuan itu bisa saja maskulin dan lakilaki bisa saja feminin. Konstruksi yang dilakukan pada saat masih bayi, perempuan di ajari untuk menjadi lembut, di kasih boneka, ga boleh main bola dll, sedangkan laki-laki-laki di ajari jadi orang yang maco, kuat, main bola, mobil mobilan, inilah suatu konstrusi yang tidak di sadari yang dianggap sebagai kodrat sehingga ini terlihat natural bahwa hal ini adalah kondat baik itu laki-laki maupun perempuan.

Mamah Dedeh pun melanjutkan dalam dakwahnya "Kalo suaminya ngasih duit, sabar penuh perhatian tidak pernah selingkuh apalagi kawin lari, dan tidak menyakiti istrnya lalu istrinya meninggalkan rumah pasti si istri itu berdosa.." pernyataan ini sangat bias gender bahwa perempuan tidak bisa meninggalkan rumah dan laki-laki boleh boleh saja. Perempuan selalu di kaitkan dengan dosa, perempuan seakan-akan 
tidak punya pilihan lain kecuali mentaati suaminya. Pernyataan-pernyaataan yang selalu mengaitkan perempuan dengan dosa menjadikan perempuan takut mengakses ruang publik, perempuan terkungkung dalam hegemoni penafsiran agama yang di sampaikan oleh para pendakwah. Budaya patriarki tidak hanya datang melalui suatu konstruksi sosial maupun budaya melainkan juga dari sebuah pemahaman pemahaman agama. Pemberian dakwah seperti ini bisa saja mempengaruhi objek dakwah $\left(M a^{\prime} d u\right)$ dan mereka akan terus menerus melanggengkan budaya patriarki jika mereka menerima begitu saja materi dakwah ini.

c. Seorang Istri tidak boleh melebihi suara suami

Mamah Dedeh mengatakan bahwa seorang istri dituntut tidak boleh bersuara keras, karena istri seperti ini akan dianggap perempuan yang durhaka. Hanya suamilah yang bisa bersuara keras terhadap istri.

d. Istri wajib melayani suami

Seorang istri wajib melayani suaminya dalam keadaan apapun Mamah Dedeh mengatakan bahwa walaupun posisi perempuan sudah dandan cantik mau bepergian ke suatu tempat dan suaminya melihat istrinya cantik dan sudah dandan dan meminta istrinya melayaninya saat itu maka seorang perempuan tidak boleh menolak.ia harus memberikan pelayanan kepada suaminya (VDVC religi 2020).

\section{Kesimpulan}

Budaya patriarki sudah ada sejak zaman dahulu bahkan sampai hari ini budaya patriarki masih saja di langgengkan. Dalam materi dakwahnya Mamah Dede pun banyak di temukan bahwa materi-materi yang di sampaikan banyak melanggengakan budaya patriarki pertama, Suami adalah kepala keluarga dan istri jadi kepala rumah tangga dari kaluarga suaminya, ngurusin anak ngurusin rumah tangga itu pekerjaan istri". Pernyataan ini sangat patriarki karena menjadikan perempuan nomor dua sedangkan laki-laki nomor satu. Kedua, Saya lebih memilih bekerja di dalam rumah daripada bekerja di kantor walaupun berpendidikan tinggi. Pernyataan kedua ini memberikan suatu pemahaman bahwa perempuan tidak layak untuk bekerja di luar, perempuan lebih pantas bekerja di dalam rumah.

Pemahaman terhadap ayat-ayat alquran dan hadits membutuhkan suatu penafsiran ulang dengan melihat konteksnya yaitu perbedaan zaman dulu dan zaman sekarang agar tidak menimbulkan bias gender ataupun pelanggengan budaya patriarki. 


\section{DAFTAR PUSTAKA}

Adrika Fithrotul Aini. 2015. "AGAMA

MENOLAK PATRIARKISME” 15: 14.

Darwin, Muhadjir, ed. 2001. Menggugat

Budaya Patriarkhi. Ed. 1. Yogyakarta:

Kerja sama Ford Foundation dengan Pusat

Penelitian Kependudukan, Universitas Gadjah Mada.

Dwijowijoto, Riant Nugroho. 2008. Gender Dan Strategi PengarusUtamaannya Di Indonesia. Cet. 1. Yogyakarta: Pustaka Pelajar.

Harjani Hefni, Munzier Supatra, and M Yunan Yusuf. 2003. Metode Dakwah. Ed. 1, [Cet. 1]. Jakarta: Kencana ;Prenada Media.

Khoiruddin Nasution. 2016. Pengantar Studi Islam: Dilengkapi PEndekatan Integrasi-Interkoneksi (Multidisipliner). Jakarta: Rajawali Pers.

Mosse, Julia Cleves, and Mansour Fakih. 2007. Gender \& pembangunan. Yogyakarta: Pustaka Pelajar.

Pierre Bourdieu. 2010. Dominasi Maskulin. Yogyakarta: Jalasutra.
Samsul Munir Amin, and Achmad Zirzis. 2009. Ilmu dakwah. Jakarta: Amzah.

Siyoto, Sandu, and Muhammad Ali Sodik. 2015. DASAR METODOLOGI PENELITIAN. Literasi Media Publishing.

Sylvia Walby. 2014. Teorisasi Patriarki. Yogyakarta: Jalasutra.

VDVC religi. 2020. Para Istri Wajib Nonton Ini!! Hak Seorang Suami Yang Perlu Kamu Tahu | Rumah Mamah Dedeh TvOne.

https://www.youtube.com/watch? $\mathrm{v}=\mathrm{km} 2 \mathrm{~m}$ hR0g33U. 